\title{
Pelaksanaan Hak Pemberi Bantuan Hukum Litigasi Selain Advokat di Pengadilan Agama Pekanbaru Berdasarkan Undang-Undang Nomor 16 Tahun 2011 tentang Bantuan Hukum
}

\author{
Robert Libra*, Wilda Arifalina \\ Dosen Fakultas Hukum Universitas Lancang Kuning \\ Jalan Yos Sudarso Km 8, Rumbai, Kota Pekanbaru, Indonesia
}

\begin{abstract}
Abstrak
Tujuan penelitian ini untuk menjelaskan pelaksanaan hak pemberi bantuan hukum litigasi selain advokat di Pengadilan Agama Pekanbaru berdasarkan Undang-Undang Nomor 16 Tahun 2011 tentang Bantuan Hukum. Jenis penelitian ini hukum sosiologi pendekatannya empiris dengan cara menelaah perumusan masalah yang hendak diteliti sekaligus memberikan gambaran dan analisis terhadap pelaksanaan hak pemberi bantuan hukum litigasi selain advokat di Pengadilan Agama Pekanbaru berdasarkan Undang-Undang Nomor 16 Tahun 2011 tentang Bantuan Hukum. Pelaksanaan hak pemberi bantuan hukum litigasi selain advokat di Pengadilan Agama Pekanbaru secara mutatis mutandis berlaku seperti advokat dalam menangani perkara profesional. Bentuknya dapat sebagai pendamping hukum berdasarkan surat kuasakhusus, sebagai kuasa dalam surat gugatan, sebagai kuasa dalam catatan gugatan apabila diajukan secara lisan atautulisan, sebagai kuasa penggugat atau tergugat di dalam persidangan. Syaratnya telah terdaftar sebagai pemberi bantuan hukum pada $\mathrm{OBH}$ yang terakreditasi. Walaupun pemberi bantuan hukum selain advokat sudah diterima di Pengadilan Agama Pekanbaru, akan tetapi belum ada pemberi bantuan hukum selain advokat sebagai pemberi bantuan hukum bagi masyarakat tidak mampu.
\end{abstract}

Kata Kunci: Bantuan Hukum, Selain Advokat, Pengadilan Agama Pekanbaru

\begin{abstract}
The purpose of this study is to explain the implementation of the right to provide legal aid to litigation in addition to advocates in the Pekanbaru Religious Court based on Law Number 16 of 2011 concerning Legal Aid. This type of research is an empirical approach to sociology by examining the formulation of the problem to be examined as well as providing an overview and analysis of the implementation of the rights of legal aid litigants in addition to advocates in the Pekanbaru Religious Court Based on Law Number 16 of 2011 concerning Legal Aid. The implementation of the right to provide legal aid to litigation in addition to advocates in the Pekanbaru Religious Court mutatis mutandis applies as advocates in handling professional cases. The form can be as a legal accomplice based on a special power of attorney, as the power of attorney in the lawsuit, as the power of attorney in the claim if submitted verbally or in writing, as the power of the plaintiff or the defendant in the
\end{abstract}

*Penulis KorespondensiE-mail: robertlibra@unilak.ac.id 
trial. The conditions are registered as a legal aid provider in an accredited $\mathrm{OBH}$. Although legal aid providers other than advocates have been accepted in the Pekanbaru Religious Court, there are no legal aid providers other than advocates as legal aid providers for the poor.

\section{Keywords: Legal Aid, Apart from Advocates, Pekanbaru Religious Court}

\section{Pendahuluan}

Semua warga negara bersamaan kedudukannya di dalam hukum sebagaimana ditegaskan Pasal 27 ayat (1) UndangUndang Dasar Negara Kesatuan Republik Indonesia Tahun 1945 (UUD Tahun 1945). Pasal ini dikenal sebagai asas equality before the law memiliki makna semua orang memiliki hak untuk diperlakukan sama dihadapan hukum. Untuk memperoleh keadilan di peradilan semua orang diperlakukan sama dihadapan hukum tanpa membeda-bedakan agama, suku atau keturunan dan ekonomi. ${ }^{1}$

Asas tersebut memberikan perlindungan hak asasi warga negara sebagai norma mendasar. Asas equality before the law pengakuannya tidak saja sebatas politik saja, akan tetapi harus disertai perbuatan konkrit negara. Dengan demikian, konsekuensinya penguasa dan penegak hukum mesti merealisasikan asas tersebut dalam kehidupan bernegara.

Realisasi dari asas equality before the lawakan semakin konkrit dan nyata melalui Undang-Undang tentang Bantuan Hukum. Bantuan hukum merupakan non derogable rights, merupakan hak yang dalam kondisi apapun tidak dapat dikurangi dan tak dapat ditangguhkan. Hak bantuan hukum ini bukan diberikan oleh negara dan bukan belas kasihan dari negara, tetapi tanggung jawab negara dalam mewujudkan equality before the law, acces to justice, dan fair trial. Sesuai praktik internasional, ada 5 (lima) pilar mengenai bantuan hukum:

1. Accesible, bantuan hukum harus dapat diakses dengan mudah.

2. Affordability, bantuan hukum dibiayai oleh negara.

3. Sustainable, bantuan hukum harus terus ada dan tidak tergantung pada donor sehingga negara harus menganggarkannya dalam Anggaran Pendapatan dan Belanja Negara (APBN).

4. Credibility, bantuan hukum harus dapat dipercaya dan memberikan keyakinan bahwa yang diberikan adalah dalam rangka peradilan yang tidak memihak (juga saat mereka menghadapi kasus melawan negara, tidak ada keraguan tentang itu).

5. Accountability, pemberi bantuan hukum harus dapat memberikan pertanggungjawaban keuangan kepada badan pusat dan kemudian badan pusat harus mempertanggungjawabkan kepada parlemen.

${ }^{1}$ Eka Susylawati, Implementasi Perkara Prodeo Bagi Masyarakat Miskin di Pengadilan Agama Pamekasan, JurnalNuansa, Volume 10, Nomor 1, Januari-Juni 2013, hIm. 125. 
Selain Undang-Undang Bantuan Hukum, mengenai hak bantuan hukum sedikit disinggung dalam Kitab UndangUndang Hukum Acara Pidana (KUHAP) menyinggung. Namun, bantuan hukum alam KUHAP hanya mengenai kondisi untuk mendapatkan bantuan hukum. Dalam KUHAP tidak ada jabaran yang jelas tentang bantuan hukum, karena itu perlu dirumuskan pengertian bantuan hukum.

Tentang bantuan hukum terdapat dua model, yaitu ajuridicialright (model yuridisindividual) dan awelfareright (model kesejahteraan). Ajuridicialright bersifat individualistis, maksudnya setiap orang akan selalu mendapat hak untuk memperoleh bantuan hukum. Model ini berciri klasik, maksudnya tergantung pada masyarakat yang memerlukan bantuan hukum. Biasanya pencari bantuan hukum mencari advokat dan imbalan jasa advokat diberikan oleh negara. Untuk model awelfareright (model kesejahteraan) menekan bagi mereka yang tidak mampu untuk mendapatkan bantuan hukum sebagai alat untuk mendapatkan keadilan bagi seluruh rakyat. ${ }^{2}$ Keadilan, menurut Aristoteles, harus diberikan negara kepada semua orang. Terkait keadilan itu, hukum bertugas agar keadilan sampai pada semua orang. Jika ada pihak bersengketa menghadap hakim, maka mesti diperlakukan sama (audi et alteram partem). Jika pihak itu mampu dapat dibela advokat, sedangkan orang miskin dapat dibela oleh pembela umum secara pro bono publico. Pembelaan ini harus dilakukan tanpa membedakan latar belakang orang yang bersangkutan, seperti agama, keturunan, ras, etnis, keyakinan politik, strata sosioekonomi, warna kulit, dan gender. ${ }^{3}$

Kedua model bantuan hukum tersebut merupakan suatuhak yang diberikan kepada masyarakat untuk melindungi kepentingan individual dan dilain pihak sebagai suatu hak kesejahteraan dalam rangka perlindungan sosial dari negara kesejahteraan. Kedua model bantuan hukum tersebut berkembang di dunia barat pada umumnya sebagai model dasar tentang bantuan hukum. Bagi Indonesia bantuan hukum merupakan hal baru dikenal sekitar tahun 1970-an. Bantuan hukum di Indonesia pada hakikatnya mengikuti perkembangan bantuan hukum dari negaranegara maju.

Dalam kacamata tertentu, bantuan hukum berciri berbeda, yaitu legal aid dan legal assistance. Legal aid ditunjukan bagi mereka yang kurang keuangannya dan tidak mampu membayar penasihat hukum. Legal aid berarti mereka tidak mampu menyewa jasa penasihat hukum. Legal assistance lebih luas dari legal aid. Dalam legal assistance bermakna penasihat hukum sebagai ahli hukum, sehingga legal assistance bantuan hukum bagi siapa saja tanpa terkecuali. Dengan itu, ahli hukum memberikan bantuan hukum tidak terbatas

\footnotetext{
${ }^{2}$ Soerjono Soekanto,Bantuan Hukum Suatu Jaminan Tinjauan Sosio Yuridis, (Jakarta: Ghalia Indonesia, 1983), hlm. 11.

${ }^{3}$ Frans Hendra Winata, Pro Bono Publico: Hak Konstitusional Fakir Miskin Untuk Memperoleh Bantuan Hukum, (Jakarta: PT Gramedia Pustaka Utama, 2009), hlm. 2.
} 
pada masyarakat miskin saja, tetapi juga bagi yang mampu membayar prestasi. ${ }^{4}$

Bantuan hukum bukanlah semata-mata pro bono publico work, tetapi merupakan suatu kewajiban advokat (duty or obligation). Orang miskin berhak memperoleh pembelaan dari advokat atau pembela umum yang bekerja untuk organisasi bantuan hukum. Sebagai pengakuan hak individu (individual right), prinsip persamaan dihadapan hukum (equality befor the law) dijamin dalam sistem hukum Indonesia. Persamaan ini tidak mengenal pengecualian. ${ }^{5}$

Implementasi bantuan hukum dalam konteks legalaid menjadi konkrit melalui Undang-Undang Nomor 16 Tahun 2011 tentang Bantuan Hukum. Sejak sejak tahun 1998 kelahirannya sudah diadvokasi oleh para aktivis bantuan hukum. Tahun 2004 sudah dibuat draft, tahun 2009 masuk ke Program Legislasi Nasional. Barulah pada tanggal 2 November 2011 diundangkan menjadi Undang-Undang Nomor 16 Tahun 2011 tentang Bantuan Hukum. ${ }^{6}$

Berdasarkan Pasal 4 ayat (2) dan 3 Undang-Undang Nomor 16 Tahun 2011 tentang Bantuan Hukum ditentukan bahwa bantuan hukum yang diberikan oleh pemberi bantuan hukum kepada penerima bantuan hukum meliputi masalah hukum keperdataan, pidana, dan tata usaha negara, baik litigasi maupun non-litigasi. Bantuan hukum tersebut meliputi menjalankan kuasa, mendampingi, mewakili, membela, dan/atau melakukan tindakan hukum lain untuk kepentingan hukum penerima bantuan hukum.?

Dalam Undang-Undang Nomor 16 Tahun 2011 tentang Bantuan Hukum dikatakan bahwa pemberi bantuan hukum adalah lembaga bantuan hukum atau organisasi kemasyarakatan yang memberi layanan bantuan hukum. Jasa hukum yang diberikan kepada penerima bantuan hukum cuma-cuma, dalam arti mereka tidak mendapat upah dari pihak yang dibantunya, namun pemerintah akan memberikan dana bantuan untuk setiap kasus yang ditangani yang besarnya disesuaikan dengan jenis kasusnya. Dana bantuan tersebut memang tidak akan diberikan kepada semua Organisasi Bantuan Hukum (OBH), tetapi hanya kepada $\mathrm{OBH}$ yang sudah memenuhi syarat sesuai dengan Undang-Undang Bantuan Hukum. ${ }^{8}$

Dengan demikian, pelaksanaan bantuan hukum di Indonesia diseleng-

\footnotetext{
${ }^{4}$ Bambang Sunggono dan Aries Harianto, Bantuan Hukum dan Hak Asasi Manusia, (Bandung: CV Mandar Maju,1994), hlm. 9.

${ }^{5}$ Fandi Prabowo dan Rusdianto Resung, Prinsip Perlindungan yang Sama dalam Pemberian Bantuan Hukum Terhadap Pelaku Tindak Pidana Berat, Jurnal Al-Qânûn, Volume 21, Nomor 1, Juni 2018, hlm. 136.

${ }^{6}$ Laporan Tahunan Kementerian Hukum dan HAM RI tanggal 26 Juli 2013, Jakarta.

${ }^{7}$ Chyntia Wirawan, Implementasi Pemberian Bantuan Hukum Cuma-cuma (Pro Bono Publico) Dalam Perkara Pidana di Kota Medan Ditinjau Berdasarkan Undang-Undang Nomor 16 Tahun 2011 tentang Bantuan Hukum (Studi di Lembaga Bantuan Hukum Medan), Jurnal IImiah, Program Sarjana IImu Hukum Fakultas Hukum Universitas Sumatera Utara Medan,2014,hlm. 8

${ }^{8}$ Mosgan Situmorang, Membangun Akuntabilitas Organisasi Bantuan Hukum, Jurnal Recthsvinding Media Pembinaan Hukum Nasional, Volume 2, Nomor 1, April 2013, hlm. 107.
} 
garakan oleh $\mathrm{OBH}$ yang terdaftar dan terakreditasi. Untuk melaksanakan pendaftaran dan akreditasi diberikan kewenangan pada Kementerian Hukum dan HAM Republik Indonesia melalui oleh Kantor Wilayah di provinsi setempat. Fasilitas yang didapat penerima bantuan hukum, yaitu diberikan pendampingan hukum oleh advokat yang tergabung dalam OBH sampai perkara selesai. Meskipun tanpa OBH sebenarnya advokat diwajibkan memberikan bantuan hukum bagi orang atau kelompok miskin, dalam mewujudkan prinsip-prinsip negara hukum, profesi. Namun, pada kenyata-annya kewajiban advokat dalam memberikan bantuan hukum cuma-cuma terdapat banyak kendala dalam praktiknya. Oleh karena itu, menurut Ade Irawan Taufik diperlukan campur tangan negara. Permasalahannya bagaimana konsepsi bantuan hukum yang selama ini terjadi dan bagaimana sinergisitas arah bantuan hukum yang berpihak pada masyarakat miskin dan bagaimana sinergisitas peran negara dan advokat dalam pemberian bantuan hukum cuma-cuma bagi orang atau kelompok miskin. ${ }^{9}$

Secara teknis untuk mengimplementasikan bantuan hukum bagi masyarakat miskin lebih lanjut diatur dalam Peraturan Pemerintah Nomor 42 Tahun 2013 tentang Syarat dan Tata Cara Pelaksanaan Bantuan Hukum Untuk Masyarakat Miskin. Masyarakat miskin yang membutuhkan bantuan hukum menurut peraturan tersebut haruslah memiliki surat keterangan tidak mampu dari lurah atau kepala desa. Untuk menyelenggarakan bantuan hukum dilaksanakan oleh advokat, paralegal, dosen, dan mahasiswa fakultas hukum yang dikelola oleh $\mathrm{OBH}$ terakreditasi.

Berdasarkan hal tersebut pemberi bantuan hukum selain advokat dapat dilakukan oleh paralegal, dosen, dan mahasiswa fakultas hukum. Keberadaan seorang pemberi bantuan hukum mempunyai arti penting dalam memberikan jalan keluar terhadap per-masalahan yang dihadapi oleh masyarakat miskin yang membutuhkan bantuan hukum.

Eksistensi paralegal, dosen, dan maha-siswa fakultas hukum dalam $\mathrm{OBH}$ dalam memberikan bantuan hukum jelas diakui Undang-Undang Bantuan Hukum. Tetapi, eksistensinya mendapat penolakan dari beberapa advokat dengan mengajukan judicial review ke Mahkamah Konstitusi (MK) terhadap Undang-Undang Bantuan Hukum. Mahkamah Konstitus menolak judicial review para advokat tersebut dalam Putusan Nomor 88/PUU-X/2012.

Para advokat yang mengajukan judicial review diantaranya Suhardi Somomoelyono, Umar Tuasikal, Dominggus Maurits Luitnan dan Malkam Bouw. Pasal yang digugat adalah Pasal 1 ayat (1), (3), (5), (6); Pasal 4 ayat (1), (3); Pasal 6 ayat (2), (3) huruf a, b; Pasal 7; Pasal 8 ayat (1), (2) huruf a, b; Pasal 9; Pasal 10 huruf a, c; Pasal 11; Pasal 15 ayat (5); dan Pasal

\footnotetext{
${ }^{9}$ Ade Irawan Taufik. Sinergisitas Peran dan Tanggung Jawab Advokat dan Negara Dalam Pemberian Bantuan Hukum Cuma-Cuma, Jurnal Recthsvinding Media Pembinaan Hukum Nasional, Volume 2, Nomor 1, April 2013, hlm. 47.
} 
22.Pasal-pasal tersebut menurut para advokat mengandung ketidakjelasan tujuan siapa yang memberikan bantuan hukum cuma-cuma, rumusan frasa bantuan hukum dan kata advokat juga dinilai menimbulkan multitafsir.

Menurut para penggugat, bantuan hukum hanya bisa diberikan oleh para advokat sejak berlakunya Pasal 56 ayat (2) KUHAP dengan istilah penasihat hukum dan konsultan hukum dilebur menjadi istilah advokat. Karena itu, para advokat merasa dirugikan dengan keberadaan Pasal 9 huruf a juncto Pasal 1 ayat (3) Undang-Undang Bantuan Hukum yang menyebut pemberian bantuan hukum dapat dilakukan oleh lembaga bantuan hukum atau organisasi masyarakat (LSM) yang berhak melakukan rekruitmen advokat, paralegal, dosen, dan mahasiswa fakultas hukum.

Dalam pandangan para advokat tersebut, dosen, mahasiswa fakultas hukum, Lembaga Swadaya Masyarakat (LSM), dan Organisasi Masyarakat (Ormas) bukanlah penegak hukum sehingga tidak berhak memberikan bantuan hukum. Hanya saja pendapat itu dimentahkan oleh majelis hakim MK yang berpendapat pasal-pasal yang digugat itu telah mengatur batasan dan arah yang jelas mengenai bantuan hukum, pemberi bantuan hukum, standar bantuan hukum, dan kode etik advokat yang tidak mengandung pertentangan dengan UUD Tahun 1945. Majelis hakim berpendapat paralegal, dosen, dan mahasiswa fakultas hukum dapat memberikan bantuan hukum.
Sementara, kewajiban advokat dalam memberikan bantuan hukum secara cumacuma tidak dibatas, tidak dikurangi dan tidak dihilangkan oleh Undang-Undang Bantuan Hukum. ${ }^{10}$

Pemberian bantuan hukum dalam implementasinya tidak diterima selain advokat seperti di Pengadilan Agama Pekanbaru. Pengadilan Agama Pekanbaru hanya memperbolehkan advokat yang sudah disumpah untuk beracara dan mengikuti persidangan. Padahal berdasarkan Undang-Undang Bantuan Hukum, pemberi bantuan hukum bukan hanya advokat, tetapi boleh paralegal, dosen, mahasiswa fakultas hukum. Hal ini diperkuat berdasarkan Putusan Mahkamah Konstitusi Nomor 88/PUU-X/2012, akan tetapi dalam praktik hanya advokat yang dibolehkan beracara.

Hasil verifikasi/akreditasi organisasi bantuan hukum yang dilakukan oleh Kementerian Hukum dan HAM hasilnya terbagi dalam kategori A, B dan C. Berdasarkan Keputusan Menteri Hukum dan Hak Asasi Manusia Republik Indonesia Nomor M.HH-01.HN.03.03 Tahun 2016 tentang Organisasi/Lembaga Bantuan Hukum yang lulus verifikasi dan akreditasi periode tahun 2016-2018 di Provinsi Riau, terdiri dari:

1. LBH Fakultas Hukum Universitas Lancang Kuning berkedudukan di Kota Pekanbaru.

2. LBH Mahatva berkedudukan di Kota Pekanbaru.

\footnotetext{
${ }^{10} \mathrm{http}$ ///www.gresnews.com/berita/hukum/11552012-mk-putuskan-paralegal-boleh-beri-bantuan-hukum/ 0/\#sthash.Hwfw8G5E.dpu, terakhir kali diakses 14 April 2018.
} 
3. LBH Ananda berkedudukan di Kabupaten Rokan Hilir.

4. LBH YLBHI Pekanbaru berkedudukan di Kabupaten Rokan Hilir.

5. LBH KBH Riau berkedudukan di Kota Pekanbaru.

6. LBH Paham Riau berkedudukan di Kota Pekanbaru.

7. LBH Forum Masyarakat Madani Indonesia berkedudukan di Kota Pekanbaru.

Prosedur memperoleh bantuan hukum harus berpedoman pada Peraturan Pemerintah Nomor 42 Tahun 2013 tentang Syarat dan Tata Cara Pelaksanaan Bantuan Hukum Untuk Masyarakat Miskin. Menurut ketentuannya, calon pemohon bantuan hukum (masyarakat miskin) terlebih dahulu membuat permohonan tertulis yang ditujukan kepada ketua $\mathrm{OBH}$ dengan melampirkan SKTM yang dikeluarkan oleh lurah/kepala desa, foto copy Kartu Tanda Penduduk (KTP), dan Kartu Keluarga (KK).

Selanjutnya, dalam waktu 3 hari $\mathrm{OBH}$ harus memberitahukan pada penerima bantuan hukum tentang kesediaan memberikan bantuan hukum secara cumacuma. Oleh karena itu, seluruh biaya jasa advokat akan ditanggung oleh negara. Apabila permohonan diterima maka ketua $\mathrm{OBH}$ menunjuk advokat untuk mendampingi atau mewakili penerima bantuan hukum dan dilanjutkan dengan penanda-tanganan surat kuasa khusus layaknya seorang advokat dengan klien. Penerima bantuan hukum akan terus didampingi atau diwakili sampai perkara selesai. ${ }^{11}$

Seluruh organisasi OBH berhak merekrut pelaksana bantuan hukum yang terdiri dari advokat, dosen, paralegal dan mahasiswa fakultas hukum untuk menjalankan program pemerintah dalam memberikan bantuan hukum. Akan tetapi, ketika hak pemberi bantuan hukum dibatasi dengan sendirinya program dari pemerintah tidak akan berjalan maksimal. Sementara, bantuan hukum secara cuma-cuma (probono) merupakan hak warga miskin yang harus dipenuhi.

Dalam penyelidikan penulis terdapat penelitian terdahulu berkaitan dengan konteks bantuan hukum. Penulis sendiri sebelumnya pernah menulis tentang penyalahgunaan surat keterangan tidak mampu sebagai syarat penerima bantuan hukum di Riau. Penulis lain Pujiono pernah menulis tentang bantuan hukum dalam perspektif tanggung jawab Negara. Siddid Ahmad melakukan penelitian tentang tanggung organisasi advokat dalam memberikan bantuan hukum untuk masyarakat miskin. Penelitian Chyntia Wirawan, dalam penelitiannya menekankan penerapan bantuan hukum pro bono publico di Kota Medan. Hasil penelitiannya menjelaskan penerapan bantuan hukum tersebut masih sangat kurang dan perlu dikembangkan lagi. Dalam pemberian bantuan hukum, pemberi bantuan hukum sebenarnya sudah cukup aktif. Namun, dapat dilihat masih kurangnya kerja sama antara

\footnotetext{
${ }^{11}$ Wawancara dengan Helen dari Divisi Pelayanan Hukum Kantor Wilayah Riau Kementerian Hukum dan Hak Asasi Manusia pada tanggal 15 Maret 2017 jam 15.00 Wib.
} 
negara dengan pihak pemberi bantuan hukum dalam hal pelaksanaan ketentuan Undang-Undang Nomor 16 Tahun 2011 tentang Bantuan Hukum. Di sisi lain, masyarakat miskin yang hendak memperoleh bantuan hukum secara cuma-cuma juga masih terkendala dengan persoalan administrasi. Demikian pula, masih banyak oknum penegak hukum yang tidak menjalankan pemberian bantuan hukum pro bono ini dengan baik. ${ }^{12}$ Memperhatikan penelitian terdahulu itu tidak menyentuh tentang pelaksanaan hak pemberi bantuan hukum litigasi selain advokat di Pengadilan Agama Pekanbaru berdasarkan UndangUndang Nomor 16 Tahun 2011 tentang Bantuan Hukum.

Oleh karena pelaksanaan hak pemberi bantuan hukum litigasi selain advokat belum pernah diteliti maka permasalahan dalam penelitian ini adalah bagaimanakah pelaksanaan hak pemberi bantuan hukum litigasi selain advokat di pengadilan agama pekanbaru berdasarkan Undang-Undang Nomor 16 Tahun 2011 tentang Bantuan Hukum? Relevan dengan permasalahan tersebut maka penelitian ini penting dilakukan karena akan menjelaskan pelaksanaan hak pemberi bantuan hukum litigasi selain advokat di Pengadilan Agama Pekanbaru berdasarkan Undang-Undang Nomor 16 Tahun 2011 tentang Bantuan Hukum.

\section{Metode Penelitian}

\section{Jenis penelitian}

Jenis penelitian ini hukum sosiologi pendekatannya empiris dengan cara menelaah perumusan masalah yang hendak diteliti sekaligus memberikan gambaran dan analisis terhadap pelaksanaan hak pemberi bantuan hukum litigasi selain advokat di Pengadilan Agama Pekanbaru Berdasarkan Undang-Undang Nomor 16 Tahun 2011 tentang Bantuan Hukum.

\section{Lokasi penelitian}

Penelitian dilakukan di Pengadilan Agama Pekanbaru.Pertimbangan penulis memilih lokasi ini karena fenomena pelaksanaan hak pemberi bantuan hukum litigasi selain advokat di Pengadilan Agama Pekanbaru masih terjadi masalah.

\section{Populasi dan sampel}

a. Populasi

Populasi yang terkait dengan penelitian ini diantaranya Ketua LBH Fakultas Hukum Universitas Lancang Kuning sebagai pelaksana pos bantuan hukum di Pengadilan Agama Pekanbaru, Kepala Divisi Yankum Kanwil Kementerian Hukum dan HAM Riau.

b. Sampel Jumlah dari masing-masing populasi di atas sebanyak 1 (satu) orang maka secara sensus keseluruhannya ditetapkan menjadi sampel.

\section{Sumber data}

a. Data primer Data primer diperoleh dan dikumpulkan melalui informasi dari sampel secara langsung, mengenai

\footnotetext{
${ }^{12}$ Chyntia Wirawan, Implementasi Pemberian...Op.Cit.,hlm. 24.
} 
hal-hal terkait dengan masalah yang diteliti.

b. Data sekunder

Data sekunder diperoleh melalui kepustakaan yang bersifat mendukung data primer.

c. Data tertier

Data tertier diperoleh melalui ensiklopedi dan yang sejenisnya yang berfungsi untuk mendukung data primer dan data sekunder.

\section{Teknik pengumpulan data}

a. Observasi

Teknik ini dilakukan dengan cara pengamatan langsung terhadap permasalahan yang diteliti.

b. Wawancara

Wawancara dilakukan secara terstruktur, yaitu tanya jawab antara penulis dengan sampel terikat dengan daftar pertanyaan yang telah disiapkan sesuai dengan arah permasalahan yang diteliti.

c. Kajian kepustakaan

Metode pengumpulan data ini dilakukan melalui peran aktif penulis untuk membaca kepustakaan yang memiliki korelasi dengan permasalahan yang diteliti.

\section{Analisis data}

Data atau informasi yang diperoleh melalui teknik wawancara dikumpulkan dan disajikan dalam bentuk uraian kalimat (deskriptif), kemudian dianalisis secara kualitatif dan menghubungkannya dengan peraturan perundang-undangan, konsep, teori, pandangan para ahli serta data lainnya yang keseluruhannya relevan dengan penelitian dan disajikan secara deskritif. Dari pembahasan tersebut penulis menarik kesimpulan dalam penelitian ini dengan "metode induktif", yakni mengambil kesimpulan dari pernyataan yang bersifat khusus untuk ditarik kesimpulan secara umum.

\section{Pembahasan}

Pelaksanaan Hak Pemberi Bantuan Hukum Litigasi Selain Advokat di Pengadilan Agama Pekanbaru

UUD Tahun 1945 dalam Pasal 24 ayat (1) menegaskan bahwa kekuasaan kehakiman merupakan kekuasaan yang merdeka untuk menyelenggarakan peradilan guna menegakkan hukum dan keadilan. Pasal 24 ayat (2) UUD Tahun 1945 menentukan bahwa kekuasaan kehakiman dilakukan oleh sebuah Mahkamah Agung dan badan peradilan dibawahnya dalam lingkungan peradilan umum, lingkungan peradilan agama, lingkungan peradilan militer, lingkungan peradilan tata usaha negara, dan oleh sebuah Mahkamah Konstitusi. Undang-Undang Nomor 7 Tahun 1989 tentang Peradilan Agama sebagaimana telah diubah dengan Undang-Undang Nomor 3 Tahun 2006 tentang Peradilan Agama pada dasarnya untuk mewujudkan penyelenggaraan kekuasaan kehakiman yang merdeka dan peradilan yang bersih serta berwibawa, yang dilakukan melalui penataan sistem peradilan yang terpadu (integrated justice system), terlebih peradilan agama secara konstitusional merupakan badan peradilan di bawah Mahkamah Agung. 
Pengadilan Agama, merupakan peradilan yang berkuasa memeriksa, memutus, dan menyelesaikan perkara perdata tertentu diatur dalam Pasal 49 Undang-Undang Nomor 7 Tahun 1989 ayat (1) terhadap kalangan golongan rakyat tertentu, yaitu orang-orang yang beragama Islam berdasarkan hukum Islam. Seiring dengan begitu banyaknya perkara bidang perkawinan yang harus ditangani oleh Pengadilan Agama maka kesempatan pemberi bantuan hukum selain advokat tentu akan semakin banyak.

Sebelum berlakunya Undang-Undang Bantuan Hukum, pemberi bantuan hukum dikenal masyarakat sebagai berikut. ${ }^{13}$

\section{Advokat}

Ketentuan advokat diatur dalam Undang-Undang Nomor 18 Tahun 2003 tentang Advokat dan Kode Etik Advokat tanggal 23 Mei 2002. Berdasarkan Undang-Undang Nomor 18 Tahun 2003, jasa hukum yang diberikan advokat meliputi bantuan hukum, pemberian konsultasi hukum, menjalankan kuasa, mendampingi, mewakili, membela, serta melakukan tindakan hukum lain untuk kepentingan hukum kliennya. Ruang lingkup pemberian jasa hukum oleh advokat cakupannya lebih luas karena advokat wajib memberikan bantuan hukum tidak hanya kepada kliennya, melainkan juga kepada masyarakat yang memerlukannya. Profesi advokat merupakan profesi yang mulia dan terhormat (officium nobile) dan karenanya dalam melaksanakan tugas profesinya sebagai penegak hukum di pengadilan posisinya sejajar dengan jaksa dan hakim.

2. Pokrol (pengacara praktek).

Pokrol (pengacara praktek) ini diatur dalam Peraturan Menteri Kehakiman Nomor 1 Tahun 1965 tanggal 28 Mei 1965. Esensinya tugas dan fungsi pokrol sama dengan advokat. Letak perbedaannya dari latar belakang pokrol bukan dari sarjana hukum. Selain itu, advokat umumnya berasal dari kalangan elite yang strata sosialnya lebih tinggi telah menempuh pendidikan tinggi, sedangkan pokrol banyak berasal dari daerah terpencil. Kebanyakan advokat menangani klien besar, sedangkan pokrol menangani sisanya. Tetapi, pasca UndangUndang Nomor 18 Tahun 2003 tentang Advokat, maka eksistensi pokrol sudah tidak ada.

3. Fakultas hukum.

Pemerintah melalui Surat Edaran Mahkamah Kehakiman Rl cq. Direktorat Jenderal Pembinaan Badan-Badan Peradilan tanggal 12 Oktober 1974 Nomor 0466/Sek/DP/ 74 mengakui secara resmi bantuan hukum oleh Fakultas. Surat edaran itu menyatakan bahwa program bantuan hukum dari Fakultas Hukum adalah

\footnotetext{
${ }^{13}$ M. Yahya Harahap, Pembahasan Permasalahan dan Penerapan KUHAP_Penyidikan dan Penuntutan, (Jakarta: Sinar Grafika, 2006), hlm. 350.
} 
program pendidikan keterampilan yang sudah menjadi kebijaksanaan pemerintah. Pelaksanannya dapat melibatkan mahasiswa dan staf pengajar di fakultas hukum tersebut.

4. Lembaga Bantuan Hukum (LBH) Persatuan Advokat Indonesia (PERADIN) membidani lahirnya LBH di Indonesia melalui ongres Nasional pada tanggal 26 Oktober 1970. Konsep dan program LBH diantaranya:

a. Lapisan masyarakat kecil yang tidak berpunya merupakan fokus bantuan dan nasihat hokum.

b. Buruh, tani, nelayan, dan pegawai negeri yang merasa haknya dilanggar dapat meminta nasihat hukum di luar pengadilan.

c. Baik perkara perdata dan pidana dapat didampingi dan diberikan bantuan hukum secara langsung di sidang pengadilan.

d. Secara cuma-Cuma memberikan bantuan dan nasihat hukum.

5. Organisasi advokat.

Berdasarkan Pasal 32 ayat (4) Undang-Undang Nomor 18 Tahun 2003 tentang Advokat, wadah tunggal organisasi advokat tidak berhasil dibentuk. Peranan organisasi advokat penting dalam mensupervisi, mendidik anggota-nya sehingga tidak ada penyimpangan advokat yang merugikan masyarakat, terutama masyarakat kecil.
Berlakunya Undang-Undang Nomor 18 Tahun 2003 tentang advokat memberikan maka advokat yang berpraktik di Pengadilan Agama memiliki kewenangan yang sama dengan advokat yang berpraktik di wilayah pengadilan lain. Akan tetapi, yang membedakannya mengenai jenis perkara yang menjadi kewenangan peradilan itu sendiri. Kewenangan menangani perkara perdata untuk orang yang beragama Islam merupakan kewenangan Pengadilan Agama. Karenanya advokat yang beracara di Pengadilan Agama tidak berperan sebagai kuasa hukum, tetapi sebagai kuasa khusus, karena hanya menangani urusan perdata bukan pidana. Bagi advokat pemberian bantuan hukum berdasarkan nilai kemanusiaan merupakan kedermawanan profesi dan tanggung jawab profesi (profesional responsibility). ${ }^{14}$

Setelah lahirnya Undang-Undang Nomor 16 Tahun 2011 tentang Bantuan Hukum, maka pendanaan bantuan hukum dibebankan pada APBN dan dapat berasal dari hibah atau sumbangan dan/atau sumber pendanaan lain yang sah dan tidak mengikat. Tata cara pemberian bantuan hukum diatur lebih lanjut dalam Peraturan Pemerintah Nomor 42 Tahun 2013 tentang Syarat dan Tata Cara Pemberian Bantuan Hukum dan Penyaluran Dana Bantuan Hukum.

Untuk dapat beracara di Pengadilan Agama, seorang advokat/pemberi bantuan hukum harus memenuhi persyaratan secara normatif/memiliki hak, yaitu

${ }^{14}$ T. Mulya Lubis, Bantuan Hukum dan Kemiskinan Struktural, (Jakarta: LP3ES, 1986), hlm. 1. 
1. Harus mempunyai surat kuasa khusus.

2. Ditunjuk sebagai wakil atau kuasa dalam surat gugatan.

3. Ditunjuk sebagai wakil atau kuasa dalam catatan gugatan apabila diajukan secara lisan atau tulisan.

4. Ditunjuk sebagai penggugat atau tergugat sebagai kuasa atau wakil di dalam persidangan.

5. Telah terdaftar sebagai advokat/ pemberi bantuan hukum pada organisasi bantuan hukum yang terakreditasi.

6. Ditunjuk berdasarkan surat penunjukkan pemberi bantuan hukum oleh lembaga bantuan hukum terakreditasi.

7. Membuat surat pernyataan kesediaan memberikan bantuan cuma-cuma.

8. Membuat surat pernyataan akan hadir pada sidang pertama.

Seluruh persyararatan diatas harus dilampirkan dalam pengajuan gugatan atau permohonan di Pengadilan Agama. Hal yang sama juga berlaku di Pengadilan Agama Pekanbaru.Adapun peran pemberi bantuan hukum selain advokat dalam Pengadilan Agama sebagai berikut.

1. Mempercepat penyelesaian perkara administrasi, baik permohonan cerai talak maupun gugatan cerai bagi kelancaran persidangan dipengadilan.

2. Membantu menghadirkan para pihak yang berpekara di pengadilan sesuai dengan jadwal persidangan.
3. Memberikan pemahaman hukum yang berkaitan dengan duduk perkara dan posisinya, terhadap para pihak dalam menyampaikan permohonan atau gugatan atau menerima putusan pengadilan agama.

Pemberi bantuan hukum litigasi selain advokat di Pengadilan Agama Pekanbaru memiliki hak yang sama layaknya seorang advokat profesional, yaitu

1. Memperoleh surat kuasa/tanda tangan kuasa dari klien dalam hal ini masyarakat tidak mampu dan mendaftarkan surat kuasa tersebut di kepaniteraan Pengadilan Agama Pekanbaru. Pada tahun 2017 di Pengadilan Agama Pekanbaru, hanya advokat yang memiki kartu tanda advokat dan berita acara sumpah yang boleh mendaftarkan surat kuasa. Untuk pemberi bantuan hukum selain advokat tidak bisa, akan tetapi pada tahun 2018 sudah bisa dengan tambahan beberapa surat, yaitu ditunjuk berdasarkan surat penunjukkan pemberi bantuan hukum oleh lembaga bantuan hukum terakreditasi. Kemudian membuat surat pernyataan kesediaan memberikan bantuan cuma-cuma serta membuat surat pernyataan akan hadir pada sidang pertama.

2. Mendampingi dalam proses mediasi apabila seluruh para pihak hadir pada sidang pertama. Mediasi di Pengadilan Agama Pekanbaru, memiliki kebiasaan, yaitu hanya para 
pihak dan advokat yang boleh masuk. Selain advokat tidak boleh masuk dalam ruangan mediasi.

3. Mendampingi pada sidang pertama. Pada Pengadilan Agama Pekanbaru pemberi bantuan hukum wajib membuat surat pernyataan kehadiran pada sidang pertama dan apabila tidak hadir majelis hakim menunda hari sidang.Apabila juga tidak hadir perkara tidak dilanjutkan, padahal dalam ketentuan surat kuasa boleh diganti atau inperson datang sendiri.

4. Mendampingi klien pada sidang lanjutan (sidang pembacaan gugatan, jawaban, replik, pembuktian, kesimpulan).

Dalam menangani kasus di Pengadilan agama Pekanbaru khususnya kasus perceraian ada beberapa peranan yang dilakukan oleh pemberi bantuan hukum selain advokat diantaranya, memberikan pelayanan hukum, memberikan nasehat hukum, membela kepentingan klien, dan mewakili klien di muka pengadilan:

1. Memberikan pelayanan hukum Peranan pemberi bantuan hukum selain advokat dalam kasus perceraian tampak sekali dalam setiap proses perkara. pemberi bantuan hukum selain advokat berupaya semaksimal mungkin memberikan advis (pelayanan) kepada kliennya dengan baik. Dalam memberikan pelayanannya, pemberi bantuan hukum ini terlebih dahulu menanyakan yang menjadi penyebab keinginannya mengajukan perceraian. Sebagai langkah awal, pemberi bantuan hukum selain advokat juga memberikan alternatif jalan damai yang dimungkinkan agar permasalahan yang dihadapi kliennya bisa memperoleh penyelesaian tanpa harus dimajukan ke sidang pengadilan. Meski akhirnya kasus yang menimpa kliennya juga masuk di meja pengadilan.

2. Memberikan nasehat hukum Pemberian nasehat hukum kepada klien yang menjadi tanggungjawab pemberi bantuan hukum selain advokat diberikan semenjak pertama kali ia berhadapan muka dengan klien. Nasehat hukum ini diberikan agar klien memiliki kesadaran hukum terhadap permasalahan yang sedang dihadapi. Bisa dimungkinkan dengan adanya nasehat awal ini ia dapat rujuk kembali dan mencabut rencananya untuk mengajukan gugatan lewat pengadilan. Dalam nasehatnya pemberi bantuan hukum memberikan pandangan bahwa pengadilan merupakan alternatif terakahir apabila terpaksa harus ditempuh lewat jalur hukum.

3. Membela kepentinganklien

Pemberi bantuan hukum selain advokat memiliki peranan membela kepentingan masyarakat dan kliennya. Pemberi bantuan hukum selain advokat dibutuhkan pada saat seseorang menghadapi masalah atau problem di bidang hukum. Peran membela kepentingan klien dalam menangani kasus perceraian dalam 
hal ini menanggung arti bahwa pembelaan bersifat absolut.

4. Mewakili klien di mukapengadilan Berdasarkan hasil wawancara dengan Winda Annisa, selaku staf di Pos Layanan Hukum Pengadilan Agama Pekanbaru, pada tanggal 23 April 2018 di Pengadilan Agama Pekanbaru menjelaskan tidak semua orang yang berperkara di Pengadilan Agama Pekanbaru dapat menghadiri setiap sesi persidangan. Adakalanya sebagian sesi diikuti oleh para pihak yang berpekara dan ada pula yang tidak. Disinilah tentunya peranan pemberi bantuan hukum selain advokat. Sebagai penerima surat kuasa dari kliennya, tentu ia memiliki andil dalam setiap sesi sebagai wakil di dalam persidangan. Secara formal ia dapat bersikap membela kepentingan dan memperjuangkan hak-haknya kliennya.

Sebagaimana telah disinggung pemberi bantuan hukum selain advokat dapat dilakukan oleh paralegal, dosen dan mahasiswa fakultas hukum. Saat ini, paralegal memerankan fungsi yang strategis dan penting dalam gerakan pemberdayaan hukum di masyarakat. Paralegal berfungsi sebagai perantara atau jembatan masyarakat pencari keadilan. Sebagai perantara paralegal memainkan peran penting dalam pembelaan hak dan kepentingan masyarakat. Hal ini mengingat $\mathrm{OBH}$ merupakan akses utama untuk memberi bantuan hukum bagi masyarakat miskin.
Peran strategis paralegal ini dibutuhkan dalam bidang perlindungan hak-hak masyarakat yang sedang berhadapan dengan hukum baik melalui proses litigasi maupun non litigasi. Sumber daya advokat yang minim dalam suatu OBH dengan sendirinya akan menghadapi kendala dalam memperjuangkan hak-hak masyarakat yang sedang berurusan dengan hukum. Pemberi bantuan hukum secara litigasi namun belum memiliki berita acara sumpah akan diusir oleh majelis hakim di Pengadilan Agama Pekanbaru. Pendapat ini berbeda dengan peranan yang dilakukan oleh pemberi bantuan hukum selain advokat di atas. Padahal berdasarkan Undang-Undang Nomor 16 Tahun 2011 tentang Bantuan Hukum paralegal diperbolehkan beracara di pengadilan. Mekanisme ini diperkuat dalam Peraturan Menteri Hukum dan HAM (Permenkumham) Nomor 1 Tahun 2018 tentang Paralegal dalam Pemberian Bantuan Hukum. ${ }^{15}$

Wawancara dengan Helen dari Divisi Pelayanan Hukum Kantor Wilayah Riau Kementerian Hukum dan HakAsasi Manusia pada tanggal 15 Maret 2018 jam 15.00 Wib mengatakan layanan pembebasan biaya perkara diperoleh oleh pemberi bantuan hukum selain advokat setelah mengajukan gugatan atau permohonan bahwa pemohon merupakan golongan yang tidak mampu berdasarkan Surat Keterangan Tidak Mampu (SKTM) yang dilampirkan oleh pemberi bantuan hukum. Bagi pihak $\mathrm{OBH}$, jika syarat mendapatkan bantuan hukum secara formal hanya berdasarkan SKTM,

${ }^{15}$ Wawancara dengan Fahmi dari LBH FH Unilak pada tanggal 24 April 2018 jam 15.00 Wib. 
sementara SKTM itu tidak selektif atau mudah didapat maka hak mendapatkan bantuan hukum sejatinya hak orang miskin, tapi justru dinikmati orang kaya. Selama belum ada syarat dan kriteria yang jelas menentukan kriteria miskin maka bagi OBH akan sulit menentukan kriteria miskin. Jika tidak ada solusinya maka siapa saja yang mengajukan permohonan bantuan hukum membawa SKTM maka secara formal sudah dianggap miskin. Terhadap fenomena ini, perlu solusi atau upaya sehingga penyalahgunaan SKTM sebagai syarat penerima bantuan hukum secara cumacuma bagi masyarakat miskin.

Menurut panitia pengawas daerah upaya yang harus dilakukan panitia pengawas daerah harus segera menyusun regulasi persyaratan materil menentukan kriteria miskin yang berhak memperoleh bantuan hukum secara cuma-cuma dari negara. Kemudian mensosialisasi-kannya kepada seluruh pemerintahan kota/ kabupaten di Provinsi Riau supaya bisa diteruskan ke kelurahan/desa sampai ke tingkat RT. Panitia Pengawas daerah sendiri terdiri dari Divisi Pelayanan Hukum Kanwilkumham Riau dan Biro Hukum Provinsi Riau. Pada Pengadilan Agama Pekanbaru setelah pemohon pembebasan biaya perkara diajukan maka akan ditelaah dan analisisterlebih dahulu oleh Ketua Pengadilan Agama disetujui atau tidak karena ini terkait dengan pemberian dana bantuan hukum yang tepat sasaran.

\section{Simpulan}

Pelaksanaan hak pemberi bantuan hukum litigasi selain advokat di Pengadilan
Agama Pekanbaru secara mutatis mutandis berlaku seperti advokat dalam menangani perkara profesional. Bentuknya dapat sebagai pendamping hukum berdasarkan surat kuasa khusus, sebagai kuasa dalam surat gugatan, sebagai kuasa dalam catatan gugatan apabila diajukan secara lisan atau tulisan, sebagai kuasa penggugat atau tergugat di dalam persidangan. Syaratnya telah terdaftar sebagai pemberi bantuan hukum pada $\mathrm{OBH}$ yang terakreditasi. Walaupun pemberi bantuan hukum selain advokat sudah diterima di Pengadilan Agama Pekanbaru, akan tetapi belum ada pemberi bantuan hukum selain advokat sebagai pemberi bantuan hukum bagi masyarakat tidak mampu.

\section{Saran}

1. Sebaiknya Pemerintah mensosialisasikan adanya pemberi bantuan hukum selain advokat. Kemudian sebaiknya Pengadilan Agama Pekanbaru tidak mempersulit prosedur dalam mengajukan sebuah perkara bantuan hukum yang dijalankan selain advokat.

2. Sebaiknya Mahkamah Agung membuat regulasi dalam bentuk Peraturan Mahkamah Agung tentang hak pemberi bantuan hukum selain advokat di pengadilan agama agar terdapat keseragaman.

\section{Referensi}

Ade Irawan Taufik. Sinergisitas Peran dan Tanggung Jawab Advokat dan Negara Dalam Pemberian Bantuan Hukum Cuma-Cuma. Jurnal Recthsvinding Media Pembinaan 
Hukum Nasional. Volume 2. Nomor

1. April 2013.

Bambang Sunggono dan Aries Harianto. 1994. Bantuan Hukum dan Hak Asasi Manusia. Bandung: CV Mandar Maju.

Chyntia Wirawan. Implementasi Pemberian Bantuan Hukum Cuma-cuma (Pro Bono Publico) Dalam Perkara Pidana di Kota Medan Ditinjau Berdasarkan Undang-Undang Nomor 16 Tahun 2011 tentang Bantuan Hukum (Studi di Lembaga Bantuan Hukum Medan). Jurnal IImiah. Program Sarjana IImu Hukum Fakultas Hukum Universitas Sumatera Utara Medan. 2014.

Eka Susylawati. Implementasi Perkara Prodeo Bagi Masyarakat Miskin di Pengadilan Agama Pamekasan. Jurnal Nuansa. Volume 10. Nomor 1. Januari-Juni 2013.

Fandi Prabowo dan Rusdianto Resung. Prinsip Perlindungan yang Sama dalam Pemberian Bantuan Hukum Terhadap Pelaku Tindak Pidana Berat. Jurnal Al-Qânûn. Volume 21. Nomor 1. Juni 2018.

Frans Hendra Winata. 2009.Pro Bono Publico: Hak Konstitusional Fakir Miskin Untuk Memperoleh Bantuan Hukum. Jakarta: PT Gramedia Pustaka Utama.

Mosgan Situmorang. Membangun Akuntabilitas Organisasi Bantuan Hukum. Jurnal Recthsvinding Media Pembinaan Hukum Nasional. Volume 2. Nomor 1. April 2013.

M. Yahya Harahap. 2006.Pembahasan Permasalahan dan Penerapan KUHAP-Penyidikan dan Penuntutan. Jakarta: Sinar Grafika.

Soerjono Soekanto. 1983. Bantuan Hukum Suatu Jaminan Tinjauan Sosio Yuridis. Jakarta: Ghalia Indonesia.

T. Mulya Lubis. 1986.Bantuan Hukum dan Kemiskinan Struktural. Jakarta: LP3ES. 